Artur Pełka*

\title{
DRAMAT MIGRACYJNY: UCHODŹCY I ECHA HOLOCAUSTU W CYKLU TEKSTÓW TEATRALNYCH ELFRIEDE JELINEK ${ }^{1}$
}

Największy obok Brechta niemieckojęzyczny twórca teatralny XX w. Heiner Müller, ubolewając nad stagnacją polityczną końca wieku, przepowiedział w połowie lat 80. powrót historii do życia społecznego za sprawą potomków Büchnerowskiego Woyzecka, którzy „z Południa” - czyli z Afryki i Bliskiego Wschodu - rozpoczną swoją „drogę krzyżową”, prowadzącą do Europy². Ta profetyczna wizja autora Hamleta Maszyny zdaje się urzeczywistniać już od zamachów terrorystycznych 11 września 2001 roku i rozpętanej przez nie spirali przemocy, której pokłosiem jest też aktualny dramat uchodźców. W nowym stuleciu powrót historii zauważalny jest wyraźnie również w teatrze i twórczości dramatycznej. Teksty dla teatru, które powstają jako reakcje na aktualne wydarzenia nader często przywołują minione fakty historyczne. Nawet jeśli czynią to tylko fragmentarycznie, krytyka aktualnej sytuacji uzyskuje dzięki temu historyczne zagruntowanie, a same teksty - jako estetyczne interwencje - nabierają wymiaru politycznego. Kluczowe dla ich polityczności jest przywoływanie „pamiętanej przyszłości”, tzn. stawianie ważkich pytań o kształt przyszłości poprzez pryzmat tragicznych historycznych doświadczeń. Ten polityczny potencjał tekstów dla teatru jest pochodną specyficznych doświadczeń ich autorek i autorów w konfrontacji

* Dr hab. Artur Pełka, prof. UŁ, Uniwersytet Łódzki.

1 Artykuł ukazał się w podobnej wersji w: Korzeniowska-Bihun 2018: 127-140.

2 Chodzi o tekst Müllera Rana Woyzeck (wygłoszony przez niego w 1985 roku z okazji przyznania mu literackiej Nagrody im. Georga Büchnera) kończący się znamienną frazą: „Woyzeck jest otwartą raną. Woyzeck żyje tam, gdzie jest pies pogrzebany, pies nazywa się Woyzeck. Na jego zmartwychwstanie oczekujemy z niepokojem i/lub nadzieją, że pies powróci jako wilk. Wilk przybędzie z Południa. Gdy słońce będzie w zenicie, a on będzie stanowił jedność z naszym cieniem, rozpocznie się, w godzinie żaru, historia”. (Müller 1989: 263; przekład A. Pełka).

3 „Przyszłość pamiętana” implikuje ostrzeżenie sformułowane przez George’a Santayanę w rozprawie Rozum w sztuce, mówiące o tym, że niepamiętanie historii skazuje na powtórne jej przeżycie. 
$\mathrm{z}$ aktualnymi wydarzeniami. Tym samym zmarginalizowany przez ostatnie dziesięciolecia $\mathrm{w}$ dyskursie teatrologicznym podmiot piszący staje się ważnym elementem w debacie nad społeczną rolą teatru. Fenomen ten chciałbym zilustrować na przykładzie cyklu tekstów autorstwa Elfriede Jelinek, które od kilku lat są najczęściej - nie tylko na scenach niemieckojęzycznych - wystawianymi utworami odnoszącymi się do dramatu uchodźców.

W listopadzie 2012 roku kilkudziesięciu uchodźców, przebywających $\mathrm{w}$ położonym pod Wiedniem zamkniętym ośrodku Traiskirchen, przedostało się do stolicy Austrii, by w tamtejszym Parku im. Zygmunta Freuda zademonstrować swój sprzeciw wobec niehumanitarnych procedur przyznawania azylu przez austriackie władze. Ponieważ protestujący w prowizorycznym obozowisku narażeni byli na prowokacje i groźby ze strony sił prawicowo-nacjonalistycznych, zaczęli okupować położony w pobliżu Kościół Wotywny, w którym ostatecznie przystąpili do strajku głodowego ${ }^{4}$. $\mathrm{Na}$ wydarzenia te zareagowała Elfriede Jelinek, pisząc tekst dla teatru Die Schutzbefohlenen ${ }^{5}$ - w polskim tłumaczeniu Karoliny Bikont Podopieczni ${ }^{6}$, który opublikowany został w oryginale po raz pierwszy na stronie internetowej autorki w czerwcu roku 20137. W kolejnych miesiącach tekst ten był kilkakrotnie modyfikowany. Pod wpływem tragicznych wydarzeń na wybrzeżu Lampedusy, gdzie w październiku 2013 roku utopiło się prawie 400 uchodźców z Somalii i Erytrei, Jelinek dopisała również nowe partie tekstu. Ostatnia wersja datowana jest na koniec września 2015 roku.

W kolejnych latach, dokładnie między wrześniem 2015 roku a kwietniem 2016 roku, tekst ten uzupełniony został czterema dodatkowymi częściami, mającymi formę epilogów ${ }^{8}$. W całym tym „uchodźczym” projekcie austriackiej

${ }^{4}$ Por. też: Wąsik 2015.

5 Tekst powstał w związku z projektem na rzecz uchodźców „Kommune der Wahrheit. Wirklichkeitsmaschine” [Komuna prawdy. Maszyna rzeczywistości], realizowanym przez Nikolasa Stemanna w hamburskim Teatrze Thalia. Po czytaniu sztuki we wrześniu 2013 roku w hamburskim Kościele St. Pauli, jej prapremiera odbyła się 23.05.2014 w ramach odbywającego się w Mannheim festiwalu Teatr Świata.

${ }^{6}$ Por. Jelinek 2015. Tekst wystawiono w Polsce w Teatrze Nowym w Zabrzu (premiera 14.11.2015, reż. Katarzyna Deszcz) oraz na Scenie Kameralnej Narodowego Starego Teatru im. Heleny Modrzejewskiej w Krakowie (premiera 9.04.2016, reż. Paweł Miśkiewicz). Poza tym w maju 2015 roku odbyly się dwa czytania sztuki - w Teatrze Nowym w Łodzi (reż. Małgorzata Wdowik) oraz w Teatrze Powszechnym w Warszawie (reż. Łukasz Chotkowski).

7 Jelinek 2015a.

${ }^{8}$ W kolejności: Appendix (18.09.2015); Coda (29.09/7.10.2015); Europas Wehr. Epilog auf dem Boden [Tama Europy. Epilog na dnie] (21.12.2015/4.03.2016) oraz Philemon und Baucis [Filemon i Baucis] (10.04/21.04.2016). Wszystkie cytaty z epilogów użyte w tekście głównym zostały przetłumaczone przez autora niniejszego artykułu. 
noblistki, mającym charakter swoistego work in progress, istotna jest procesowość aktu twórczego, który towarzyszył rozwojowi wypadków w związku z eskalacją dramatu uchodźców. Ponieważ motor aktu twórczego stanowią realne wydarzenia, tekst siłą rzeczy posiada wymiar dokumentarny, nie ograniczający się jednak do literackiego sprawozdania faktów, lecz postrzegany być musi jako interwencja, wynikająca z moralnego imperatywu nakazującego wstawienie się za potrzebującymi.

W skonstruowanym na postdramatyczną modłę tekście - a zatem pozbawionym akcji, dialogów i podziału na role - pojawia się swego rodzaju auktorialne Ja, którego głos raz po raz wyłania się z nurtów tekstu, mieszając się z głosem dominującego w nim My, dającego się zidentyfikować przede wszystkim jako chór uchodźców. Nakładanie się na siebie i przecinanie się tych głosów według zasady protagonista - chór, co notabene stanowi zabieg konstytutywny dla większości ostatnich tekstów dla teatru autorstwa Jelinek, pełni w przypadku Podopiecznych funkcję szczególną. Z racji, że głos Ja zlewa się z głosem My, bądź też niejako się z niego wynurza, powstaje swoista koincydencja, w wyniku której - mimo czasowego i przestrzennego dystansu - narracja auktorialna upodabnia się do szukających azylu uchodźców, stając się de facto sama uchodźczynią. Jeśli za teatrolożką Ulrike Haas przyjąć, że chór w dramacie antycznym miał pozycję podobną do „emigranta", to chóralna forma Podopiecznych jawi się jako urzeczywistniona metafora masy marginalizowanych uchodźców, szukających swojego miejsca i upodmiotowienia. W rzeczy samej w tekście Jelinek - inaczej niż w tragedii antycznej - to nie chór ustępuje miejsca protagoniście, lecz właśnie auktorialna protagonistka umożliwia wystąpienie na scenie pozbawionemu praw kolektywowi i zapewnia mu jako swojemu "podopiecznemu” symboliczny azyl w przestrzeni tekstu teatralnego.

Strukturę Podopiecznych, składających się z 29 heterogenicznych segmentów tekstu, konstytuują dwa motywy przewodnie. $\mathrm{Z}$ jednej strony tekst odnosi się do bieżących wydarzeń związanych z dziejącym się tu i teraz dramatem uchodźców, z drugiej zaś przywołuje wartości humanistyczne cywilizacji europejskiej, które reprezentują wmontowane $\mathrm{w}$ tkankę tekstu mikro- i makroodniesienia do różnorodnych tekstów kultury. Oba motywy spaja jedna z najstarszych zachowanych tragedii greckich, a mianowicie Błagalnice Ajschylosa, stanowiąca niejako - w podwójnym tego słowa znaczeniu - pretekst dla tekstu Jelinek, co sygnalizuje już jego nawiązujący do pierwowzoru tytuł ${ }^{10}$.

Jak wiadomo, tragedia Ajschylosa opowiada o losie 50 córek Danaosa, które uciekają z Egiptu przed synami króla Ajgyptosa, chcącymi narzucić im

9 Por. Haas 2012.

10 Tytuł tragedii Ajschylosa to w niemieckim Die Schutzflehenden, czyli „błagający o wzięcie pod opiekę”, natomiast Die Schutzbefohlenen oznacza „poleceni opiece”. 
małżeństwo. Przeprawiając się pentekonterą ${ }^{11}$ wraz ze swoim ojcem przez Morze Śródziemne trafiają do Argos, gdzie błagają króla Pelazgosa o azyl, powołując się na pokrewieństwo $\mathrm{z}$ argejską kapłanką Io. Pelazgos postawiony zostaje przed dylematem, bowiem z jednej strony ryzykuje wojnę z Egiptem, z drugiej zaś gniew Zeusa jako Hikesiosa, czyli bóstwa opiekuńczego uchodźców. Ostatecznie po przeprowadzonym referendum błagalnicom zostaje udzielony azyl. I to właśnie ta antyczna humanitarność - której echo nieustannie pobrzmiewa w tekście Jelinek - w zestawieniu $\mathrm{z}$ aktualną sytuacją obnaża bezlitośnie dehumanizację europejskiej cywilizacji. Współcześni uchodźcy - choć już nie jako błagalnicy, lecz w świetle nowoczesnych praw człowieka podopieczni cywilizowanego świata - spotykają się z niechęcią, odrzuceniem i wrogością.

Dehumanizacja Europy eksplorowana jest w tekście na wielu poziomach, w sposób szczególny zainscenizowana zostaje jako dewaluacja tzw. wartości chrześcijańskich. Podczas gdy mityczne Danaidy jako istoty na poły barbarzyńskie, odwołując się w swoim błaganiu do religijnych powinności Greków, wymuszają ich wypełnienie, to nakazy chrześcijańskie nie tylko nie są wypełniane, lecz wręcz przeciwnie - współczesna, dominująca w Europie religia staje się pretekstem do tworzenia bastionu nienawiści przeciwko tzw. islamizacji Zachodu. Ciemna strona opartej rzekomo na chrześcijańskim fundamencie miłości bliźniego implikowana jest poprzez liczne rozsypane po całym tekście mikro-sceny. Ta swoista demaskacja swoje apogeum osiąga wraz z wplecionym w tekst biblijnym cytatem „pozwólcie dzieciom przychodzić do mnie”, który na tle niezliczonej liczby utonięć dzieci uchodźców podczas niebezpiecznej przeprawy przez Morze Śródziemne, staje się perwersyjną aluzją do panoszącej się w mediach społecznościowych mowy nienawiści.

Nawiązując do Błagalnic Ajschylosa Jelinek przywołuje również siłą rzeczy zakotwiczony w kulturze europejskiej topos Morza Śródziemnego jako kolebki cywilizacji i przyjaznego ludziom akwenu. Topos ten zostaje jednak w Podopiecznych przenicowany z gorzką ironią: Podczas gdy dla prześladowanych Danaid łączące trzy kontynenty morze stanowi zbawienną drogą ucieczki, to dla współczesnych uchodźców staje się ono wodnym traktem śmierci. Przyjazne locus maritimus zostaje zdegradowane do potwornego locus mortis, jest „dziurą, gardzieli otchłanią, suchym dołem” (Jelinek 2015: 77), ,morzem nieprawdziwym [...], w którym oni kończą, w końcu kończą" ${ }^{12}$, jak mówi tekst o tragedii na wybrzeżu Lampedusy. To zredukowanie morskiej tafli do śmiercionośnej otchłani wiąże się z inną przestrzenną opozycją. Perspektywa horyzontalna, dająca uchodźcom nadzieję na ratunek, zostaje przecięta i zniweczona przez wertykalność górskiego krajobrazu: „horyzont przestał istnieć, skończył się na paśmie gór” (Jelinek 2015: 77). Opozycja między głębią morza a strzelistością górskich szczytów koresponduje wyraźnie $\mathrm{z}$ hierarchią między tymi „[t]am na swojej skale, na rafie,

${ }^{11}$ Chodzi tu o statek wiosłowo-żaglowy.

${ }^{12}$ W tłumaczeniu Karoliny Bikont brakuje tego fragmentu. Por. Jelinek 2015a. 
tam na swojej górze” (Jelinek 2015: 87) a „masą [...] dzikusów” (Jelinek 2015: 103), która nie ma „prawa, do waszych gór” (Jelinek 2015: 95). Poprzez tę polaryzację przestrzeń dzieli się na dwie sfery: sferę w pewnym sensie olimpijską jako przestrzeń władzy i wolności oraz sferę otchłani jako sferę niebytu. Hierarchię tę odzwierciedla zmodyfikowany cytat zaczerpnięty ze słynnego, opisującego w mitologicznym sztafażu ludzką niedolę wiersza Hörderlina zatytułowanego Hyperion (1799), którym Jelinek puentuje egzystencjalną sytuację uchodźców: „lecą ludzie ze skały, odwiecznie szarpani jak woda” (Jelinek 2015: 83). Poprzez ten zabieg, motyw mitologicznej predestynacji sprzęgnięty zostaje z egzystencjalistycznym przekonaniem o „wrzuceniu w świat”, a woda jako życiodajny i śmiercionośny żywioł staje się wymowną metaforą opisującą los uchodźców. Jako „fal[a] napływow[a]” (Jelinek 2015: 103) obcy przybysze zredukowani zostają do dzikiej i niebezpiecznej natury, która podobnie jak morskie fale musi zostać okiełznana przez kulturę.

Horyzontalno-wertykalna opozycja pojawia się również $\mathrm{w}$ reminiscencji protestu w wiedeńskim Kościele Wotywnym, w którym Jelinek niechybnie nawiązuje do Błagalnic Ajschylosa, których bohaterki określają się jako „stado golębi”:

Gołąb zastęppą zastępcy zastępcy, nie, to gołębica, czyli zastępczyni zastępcy zastępcy, przynajmniej ptak, czyli umie latać, do niej błagalne więc modty zanoszę, rozlegają się dźwięki dzwonów, aż mi w uszach dzwoni [...], ale teraz dzwonię modlitwę do tamtej gołębicy na dachu, ubłagać by ją, ubłagać by, słoneczne oko opatrzności w trójkącie skaczące [...]. Święte miejsce obsiedliśmy niczym stado gołębi, tyle że oni tutaj znają tylko jednego gołębia, tę gołębicę na dachu, do której nie dosięgamy na pewno, za wysoko siedzi, jastrzębia się lękać nie musi, a co z nami? (Jelinek 2015: 80)

We fragmencie tym, wykorzystującym $\mathrm{w}$ subwersywny sposób motyw gołębia w symbolice judeo-chrześcijańskiej (Duch Święty, Arka Noego itd.), konstruowana jest ponownie hierarchizująca wertykalność. W pewnym sensie opisywany budynek sakralny (Kościół Wotywny) staje się odpowiednikiem góry względnie nadmorskiej skały, tworzącej złowrogą topografię. Podobnie jak gołąb również skała zostaje pozbawiona pierwotnego wymiaru biblijnego, stając się perwersyjnym miejscem stracenia, z którego strąca się „zakrwawionych" (Jelinek 2015: 98) obcych przybyszów. Nie ma dla nich dostępu do skały jako „wspóln[ego] fundament[u] wartości” (Jelinek 2015: 87), a kościelna „kołysząc[a] się naw [a]” (Jelinek 2015: 91), navis, nie gwarantuje im ratunku w „błotnist [ej] to[ni] Styksu” (Jelinek 2015: 103), jakim jawi się być niechętna uchodźcom Europa. W tym kontekście uchodźcy pozostają „w niebycie” (Jelinek 2015: 79), którego absolutną metaforą staje się woda. Życiodajny fluid posiadający zdolność ciągłej przemiany, potrafiący niejako dialektycznie niwelować przeciwieństwa, urasta w tekście Jelinek do symbolu marności uchodźczego losu: „[N]ie zrozumiecie naszej mowy, nasza mowa spłynie w pustkę, 
w nieważkość, nasz ciężki los lekkim będzie, spływając do wody, w nicość, w próżnię, tam, gdzie nic nie ma, będzie w zawieszeniu, zawiśnie w niebycie i tyle" (Jelinek 2015: 79).

W kontekście motywu wody autorka dokonuje także gorzko-ironicznej rewizji europejskiej filozofii, odnosząc się bezpośrednio do myśli Heideggera:

Stoimy w prześwicie bycia, mówi filozof, nie, to ja mówię: bycia, które jest wodą, która jest prześwitem, ograniczonym jedynie naszą śmiercią, czyli naszym niebyciem [...]: o, jak wielu z nas nigdy nie dotrze do tego bezcelu, aby rozpływać się po nieskończonym prześwicie naszego jawno-niebycia, maleńkiej przestrzeni nieskończoności ${ }^{13}$. (Jelinek 2015: 109)

Heideggerowska filozofia bezdomności ludzkiej zostaje w Podopiecznych skonkretyzowana jako brak dachu nad głową, brak mieszkania, w którym uchodźcy, mogliby mieć „posłanie i dom” (Jelinek 2015: 93). Skonfrontowane z elementarną ludzką potrzebą posiadania domu w kontekście uchodźczym, egzystencjalistyczne wywody Heideggera zostają ostatecznie bezlitośnie zdewaluowane.

Cała pentalogia przywołuje różne formy przemocy, na którą narażeni są szukający azylu uchodźcy. Jako przemoc jawi się zarówno osadzenie uchodźców poza prawem, ich redukcja do Agambenowskiego homo sacer, nagiego życia - prowadząca niechybnie do symbolicznego i realnego unicestwienia (por. Agamben 2008) - jak i ich medialnego odrzeczywistnienia, prekaryzacji, jak powiedziałaby Judith Butler, uniemożliwiającej jakąkolwiek żałobę (por. Butler 2010). Nadto cały pięcioksiąg objawia niejako strukturę głębi, generowaną poprzez odkładanie się pod powierzchnią tekstu śladów traumatycznych wydarzeń z przeszłości, jakby wypieranie traumy do subtekstu. Podopieczni wraz z tekstami uzupełniającymi implikują bowiem nieustannie koincydencję losu uchodźców i deportowanych do obozów koncentracyjnych, która ujawnia się głównie poprzez niespodziewane wypływanie na powierzchnię tekstu - niczym zwłok topielców - złowieszczych fraz: „na stojaka więcej ludu wejdzie do wagonu” ( Jelinek 2015: 84), „ludzkie fundamenty złożone z naszej miazgi” (Jelinek 2015: 88), czy też "Jesteśmy spieczeni jak chleb, chcecie nas wydostać przez bulaje” (Jelinek 2015: 88). Tym samym Jelinek w "tekstach uchodźczych” kontynuuje projekt swego „posttraumatycznego teatru” (por. Pewny 2011: 153-165) jako teatru pamięci, ewokowanego przez „upiorne manifestacje ciążącej wciąż na teraźniejszości przeszłości” (Vogel 2013: 53). W tym sensie mówiący kolektyw uchodźców jawi się jako chór upiorów, któremu w obliczu przemocy, jakiej doświadcza i o której zdaje relację, dosłownie odbiera mowę: Wypowiadane frazy potykają się o swoją własną semantykę, artykułując jedynie rozproszone, niejednoznaczne, a przez to złowieszcze sensy. Ta specyficzna upiorność tekstu generuje nieustannie efekty niesamowitości: Obcość i tajemniczość tekstu, mieszająca się z poczuciem

13 Jelinek nawiązuje tu do wykładu Heideggera wygłoszonego w semestrze zimowym 1955/1956 na Uniwersytecie we Freiburgu. Por. Heidegger 2001. 
obcowania z czymś znanym, wywołuje uczucie dyskomfortu i niepokoju. Tym, co znane, jest tu przede wszystkim wiedza o Zagładzie, wypierana wraz z przemijającym czasem i neoliberalnym przeświadczeniem o życiu po historii lub poza nią, wskrzeszana przez Jelinek dzięki jej literackiej kreacji jako upiór. Upiór ten jako „obecna nieobecność” 14 aktywuje niejako niesamowitość jako pamięć tego, co ze świadomości zbiorowej zostało wyparte.

Ze szczególnym wyrafinowaniem taki efekt niesamowitości wywoływany jest w trzecim tekście pentalogii Jelinek, noszącej tytuł Coda. Motyw przewodni stanowi tutaj podróż łodzią przez Morze Śródziemne, która pars pro toto rekonstruuje aktualne masowe czarne scenariusze ucieczki. Za wzór tej literackiej rekonstrukcji posłużył autorce dokument francuskiego reportera Francka Genauzeau, który z kamerą towarzyszył grupie uchodźców w ich nielegalnej przeprawie łodzią motorową z wybrzeża tureckiego na grecką wyspę Lesbos. Jego film pokazuje ściśniętych ludzi w chybotliwej łodzi, wyposażonej w niesprawny silnik, wyrzucający z siebie trujące opary mazutu, które zmuszeni są wdychać pasażerowie, w tym wiele dzieci.

Ta niebezpieczna odyseja „w spopielałą szarość, w gęstą czerń” (Jelinek 2015c) oddana jest po części za pomocą metaforyki i zapierającej dech parataksy rodem z Fugi śmierci Paula Celana, co sugeruje już tytuł tekstu Coda, przywołujący tak jak jego liryczny odpowiednik termin muzyczny. Niektóre z fraz zaczerpnięte $\mathrm{z}$ wiersza Celana, uważanego za najdoskonalsze poetyckie epitafium upamiętniające ofiary Zagłady, niczym językowe odłamki wrzuca Jelinek w nurt swego własnego tekstu, który wymusza zaskakujące skojarzenia:

Płyniemy w dzień, nie ma nocy, nie ma czerni, ona $\mathrm{w}$ ciągu dnia znajduje się pod wodą, a w nocy to już na pewno, jeśli Państwo koniecznie chcą się tam dostać, to zobaczycie tę czerń, to co nieprzeniknione, co z zewnątrz wygląda jakoś tak błękitnie, czy to w ogóle jest błękit, czy też jest to AdBlue? Możecie to sobie wygooglować, jeśli nie jeździcie nowoczesnym dieslem wraz z jego trującymi tlenkami, nie musicie jednak. Gdzieś tam znów duszą się ludzie, bo nie mają już czym oddychać, ja dokładnie tego nie widzę, siedzę na krześle i patrzę na zdjęcie samochodu-chłodni przewożącego mięso drobiowe, a na youtubie jest tego cała masa, całe masy, które pomieściłaby nawet ta łódź, mnie jednak nie, nie umiem pływać. (Jelinek 2015c)

Dramat uchodźców na Morzu Śródziemnym sprzężony zostaje tu asocjacyjnie z jednej strony z tzw. Aferą Volkswagena, związaną z zaniżaniem przez niemiecki koncern wyniku pomiaru emisji spalin, $\mathrm{z}$ drugiej strony $\mathrm{z}$ tragiczną

${ }^{14}$ Termin ten nawiązuje do wywodów niemieckiego literaturoznawcy Axela Dunkera, który stawia tezę, że wypieranie Holokaustu z indywidualnej i kolektywnej świadomości zostaje odwrócone przez literaturę w formie „obecności nieobecnego”, tzn. tego "co wyartykułowane zostaje jedynie implicite, a mimo to konstytuuje koherentną warstwę znaczeń w obrębie tekstu” (por. Dunker 2003: 12). 
śmiercią w wyniku uduszenia 71 uchodźców z Syrii w ciężarówce-chłodni, porzuconej na austriackiej autostradzie w sierpniu 2015 roku. Tym samym Jelinek dokonuje projekcji Zagłady na teraźniejszość względnie przywołuje za pomocą tego „niesamowitego” sprzężenia jej „nieobecną obecność”. To, co początkowo może wydawać się niekoherentne, przy wnikliwszej analizie jawi się jako wyraźna korespondencja. Podczas gdy w Aferze Volkswagena ignorowano normy emisji trujących gazów, narażając na szwank ludzkie zdrowie, w wypadku uchodźców ignoruje się humanitarne normy, co stanowi niebezpieczeństwo dla ich życia. Używana w katalizatorach, pozyskiwana z granulatu mocznikowego substancja AdBlue, jawi się $\mathrm{w}$ tym kontekście jako fantom cyklonu B, granulowanej ziemi okrzemkowej nasyconej cyjanowodorem, który stał się symbolem techniki Holocaustu. Dzięki temu niesamowitemu tertium comparationis przywoływana jest tu wszechobecność Auschwitz jako rządzącej światem „zasady selekcji”, którą nieustannie piętnowal wspomniany na początku Heiner Müller ${ }^{15}$.

Zestawienie tematu zanieczyszczenia środowiska $\mathrm{z}$ masową eksterminacją, która jako motyw pojawia się już we wcześniejszych tekstach Jelinek - szczegól-

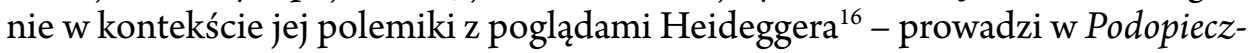
nych do krytycznej refleksji nad dążeniem po - nie tylko metaforycznych - trupach do finansowego zysku, odnoszącym się w równej mierze do śmiercionośnej maszynerii nazizmu, działań ludzi trudniących się przemycaniem uchodźców oraz strategii nowoczesnych koncernów przemysłowych. Odnośnie tych ostatnich egzemplifikowany jest właśnie temat selekcji, przede wszystkim w kontekście celebrowanej przez niemieckie media gotowości zatrudniania uchodźców przez koncern Daimlera:

Jest ich tak wielu, że muszą pogodzić się z tym, że nie mogą sobie wybierać, gdzie mogą szukać schronienia, nasza gotowość do pomocy nie może mianowicie zostać nadwyrężona, nie, nie, takie są fakty, tak jest tu napisane, w przeciwnym razie nie wiedziałabym o tym. Znów ma być wprowadzone to, co kiedyś wyprowadziliśmy, a mianowicie kontrole na granicy, żeby nie zostało wprowadzone wszystko to, czego nie potrzebujemy, to, czego nie potrzebuje również Mercedes, ta gwiazda, która słusznie dzieli ludzi na przydatnych i nieprzydatnych. (Jelinek 2015b)

15 W rozmowie z Alexandrem Kluge Müller następująco opisał tę zasadę: „Problemem naszej cywilizacji jest stworzenie alternatywy dla Auschwitz, brakuje jej więc. [...] Zatem jeśli przyjmiesz Auschwitz nie za metaforę - tak, metafora jest bardzo barbarzyńskim słowem - ale za rzeczywistość selekcji. A selekcja jest globalnie problemem polityki. Nie ma jeszcze żadnej alternatywy dla Auschwitz". (Kluge 1996: 61; por. także Müller 1995).

16 Chodzi tu przede wszystkim o wygłoszony przez Heideggera w 1949 roku w Bremie wykład Das Ge-Stell (Ze-staw), w którym filozof porównywał ludobójstwo w komorach gazowych $\mathrm{z}$ degradacją natury przez technikę. 
Humanitarny gest przemysłowego potentata, zatrudniającego w swych zakładach „wyselekcjonowanych” uchodźców zostaje przez Jelinek zdemaskowany jako „narodowa bufonada”, za którą skrywają się finansowe interesy, a ostatecznie zdemaskowany jako kontynuacja (nazistowskiego) wyzysku: „Jeszcze wczoraj Mercedes był w obozach krajów niemieckich i sortował to, co przydatne od tego, co przydać się nie może, to sprawnie u nich idzie, w przeciwnym razie nie odnieśliby takiego sukcesu" ( Jelinek 2015b).

Poprzez permanentne przywoływanie przeszłości Podopieczni zyskują status tekstu memorialnego, który przywraca pamięci to, co zostało z niej wyparte i upamiętnia to, czego $\mathrm{w}$ zasadzie nie jest $\mathrm{w}$ stanie przedstawić. To, co jest nie do wypowiedzenia i nie do przedstawienia staje się w tekstach Jelinek obecnością. Literacko udramatyzowana wersja utrwalonej przez Genauzeau na kamerze filmowej tragedii na Morzu Śródziemnym posługuje się efektem niesamowitości przede wszystkim poprzez skorelowanie ze sobą niebezpiecznych dla życia pasażerów łodzi spalin ze śmiercionośnym gazem w komorach obozów zagłady. Za gorzko-ironiczne dopełnienie tego upiornego sprzęgnięcia służy dominujący w zatytułowanej Appendix części pentalogii muzyczny motyw nocnej eskapady, zabawy bez tchu w klubach rozrywki. Podczas gdy Celanowska Fuga śmierci stanowi niejako muzyczne tło Cody, to w Appendixsie pobrzmiewa super-przebój piosenkarki Helene Fischer o wymownym refrenie „Bez tchu poprzez noc, aż nastanie dzień”. Figura „śpiewaczki bez tchu” przywołuje tutaj motyw uwodzącego śpiewu Homeryckich syren. Tym samym słynna niemiecka gwiazda muzyki pop jako nowoczesna Syrena uosabia w tekście Jelinek masową kulturę popularną, której głośny rytm zagłusza polityczne sumienie. Wymowne jest przy tym, że Helene Fischer jako tzw. Russlanddeutsche, czyli Rosjanka niemieckiego pochodzenia ma w swej nowej ojczyźnie de facto status przesiedleńca, o czym zresztą przypomina tekst Jelinek: „Nie trzeba jej już nadawać obywatelstwa, ona je ma, ona ma swoje prawa, ma prawo, by śpiewać i tańczyć, i śmiać się" (Jelinek 2015b). W tym kontekście pojawiają się jeszcze dwie inne kobiece postacie, cieszące się - w przeciwieństwie do przeciętnych uchodźców - przywilejem przyznania obywatelstwa. Chodzi tu o nietransparentny proceder przyznania austriackich paszportów rosyjskiej śpiewaczce operowej Annie Netrebko oraz córce Borysa Jelcyna Oldze Jumaszewej.

Za pomocą dekonstruktywistycznych operacji na różnorodnych tekstach kultury Jelinek artykułuje w ramach swego dokumentarnego teatru interwencji, jaki stanowią Podopieczni, swój własny ogląd dramatu uchodźców, którego pointą są wypowiedziane w finale zdania: „Nas nie ma. Dotarliśmy, ale nie ma nas wcale” (Jelinek 2015: 121). Wobec wykluczenia uchodźców Jelinek czyni słyszalnym to, co ginie w medialnym strumieniu obrazów. Kluczowym zabiegiem jest przy tym gra $\mathrm{z}$ "nieobecną obecnością” i związane z nią generowanie efektów niesamowitości. Takie literackie balansowanie między obecnością i nieobecnością, świadomością i podświadomością, zamysłem i zmysłowością przybiera formę etycznego apelu, którego przedmiotem i celem jest „pamiętana przyszłość”. 


\section{Bibliografia}

Agamben, George (2008), Homo sacer. Suwerenna wtadza i nagie życie, (tłum. Mateusz Salwa). Warszawa.

Butler, Judith (2010), Walczące słowa. Mowa nienawiści i polityka performatywu, (tłum. Adam Ostolski). Warszawa.

Dunker, Axel (2003), Die anwesende Abwesenheit. Literatur im Schatten von Auschwitz. München.

Haas, Ulrike (2012), Woher kommt der Chor. W: „Maske \& Koturn“ nr 3, 2012. Göttingen, s. 13-30.

Heidegger, Martin (2001), Zasada racji, (tłum. Janusz Mizera). Kraków.

Jelinek, Elfriede (2015), Podopieczni, (tłum. Karolina Bikont). W: „Dialog” nr 4, 2015. Warszawa, s. 75-121.

Jelinek, Elfriede (2015a), Die Schutzbefohlenen. W: http://www.a-e-m-gmbh.com/ej/ fschutzbefohlene.htm [Dostęp: 27.10.2019].

Jelinek, Elfriede (2015b), Appendix. W: http://www.elfriedejelinek.com/fsbappendix. htm [Dostęp: 27.10.2019].

Jelinek, Elfriede (2015c), Coda. W: http://elfriedejelinek.com/fschutzbefohlene-coda. htm [Dostęp: 27.10.2019].

Kluge, Alexander (1996), Ich schulde der Welt einen Toten. Gespräche, Alexander Kluge/ Heiner Müller. Hamburg.

Korzeniowska-Bihun, Anna (red.) (2018), Wspótczesny dramat i teatr wobec wojny, przemocy i uchodźstwa. Warszawa.

Müller, Heiner (1989), Die Wunde Woyzeck. W: Müller, Heiner, Shakespeare Factory 2, Berlin.

Müller, Heiner (1995), Auschwitz und kein Ende: ein Gespräch. Berlin.

Pewny, Katharina (2011), Das Drama des Prekären. Über Wiederkehr der Ethik in Theater und Performance. Bielefeld.

Santayana, George (2015), Rozum w sztuce, (tłum. Translatorium Instytutu Filozofii UMK). Toruń.

Vogel, Juliane (2013), Intertextualität. W: Janke, Pia (red.), Jelinek-Handbuch. Stuttgart, Weimar, s. 47-55.

Wąsik, Monika (2015), Święte krowy i uchodźcy. Na marginesie „Podopiecznych” Elfriede Jelinek. W: „Dialog” nr 4, Warszawa, s. 122-137. 


\title{
Artur Pełka \\ Migration drama: Refugees and echoes of the Holocaust in Elfriede Jelinek's theatre serie
}

\begin{abstract}
Influenced by events related to the spectacular protests held in Austrian refugee transit camps at the turn of 2012/13, Elfriede Jelinek created the text "The Charges" for the stage, borrowing its title from Aeschylus. This text soon became the most frequently staged - and not only - on German-speaking stages, a poignant documentary of the refugee drama. Moreover, it was updated several times by the writer, by adding more parts to it until December 2015. The resulting pentalogy not only documents the course of the mass exodus of those seeking refuge from the war, but also critically addresses its causes and, above all, the refugee policy of European countries and the related media manipulation, as well as - last but not least - the attitude towards the refugees of ordinary Europeans. In doing so, the Nobel Prize winner deconstructs the canonical texts of culture, thereby demythologizing the alleged foundation of humanism or Christian morale in Europe. An important element of this dismantling is the generation of "effects of the uncanny", consisting in recalling the ghosts of the victims of past wars and extermination, including above all the victims of Nazi genocide. Jelinek's text as an artistic intervention not only restores the idea of engaged theatre, but also - despite its pessimistic, as it were - neo-existentialist' tone - advocates a model of the 'remembered future'.
\end{abstract}

Keywords: refugees, migration, theatre, Austria, genocide

Słowa kluczowe: uchodźcy, migracja, teatr, Austria, ludobójstwo 